Who's ahead, who's behind?

Between 1967 and 1971, when immobilised enzymes were emerging as the first wave of the new biobusiness, $30 \%$ of world biotechnological patents originated in one country: the UK. But of the patents delivered since 1977, 124 originated in Japan, 39 in the US, 9 in the USSR, 8 in West Germany, 7 in France, one in Denmark, and just one in the UK.

Armed with this rather depressing information for Europe, the European Commission requested two biologists - Dr Artur Rorsch of Leiden State University, The Netherlands, and Dr Daniel Thomas of the University of Compiegne, France, to produce reports* on the status and potential of genetic manipulations in applied biology, and of the production and exploitation of biological catalysts.

Meanwhile in France, Professor Francois Gros, Director of the Institut Pasteur, Professor François Jacob, Nobel laureate and also at the Institut Pasteur, and Professor Peirre Royer of the Delegation Generale pour la Recherche Scientifique et Technique were producing a report* on biotechnology for the President of the Republic, Giscard d'Estaing.

All these reports carry reviews of the state of the art in biotechnology around the world; together they provide a worldwide picture.

\section{Japanese domination}

Japan has taken an incontestable lead in biotechnology. The company Tanabe Seiyaku is credited with the first application of immobilised enzymes in 1969. It used aminoacylase carried on DEAE-Sephadex for the continuous production of $\mathrm{L}$-amino acids from acyl-DLamino acids, reducing overall operating costs compared with a free-enzyme, batch process by $40 \%$.

Now five companies are in active production, in processes involving four different fixed enzymes - aminoacylase, aspartase, glucose isomerase, and penicillin acylase - and three fixed cells Escherichia coli, using its aspartase metabolism, Brevibacterium ammoniagenes (fumarase) and Streptomyces sp. (glucose isomerase). The Tanabe Seiyaku company has also developed processes involving fixed cells of Pseudomonas putida (L-arginine deiminase), Achromobacter liquidum (L-histidine ammonialyse), and $E$. coli (penicillin amidase). Many biotechnologists believe that the fixation of cells and cell organelles is the way forward for enzyme technology, and perhaps also

" "Genetic manipulations in applied biology" by $A$ Rorsch, catalogue number CD-NI-78-001EN-C; "Production of biological catalysts, stabilization and exploitation" by D Thomas, $C D-N I-78-002-E N-C$, available from offices for official publications of the European Communities; and "Sciences de la vie et Societe" by François Gros, François Jacob, and Pierre Royer, available from $\mathrm{La}$ Documentation francaise. for the use of genetically engineered microorganisms.

Japan's industrial interest has to some extent been stimulated by the numerous traditional fermented food industries, producing miso and shoyu and the drink sake through the Aspergillus oryzae amylases. The average consumption of miso is apparently $24 \mathrm{gm} /$ person/day, and the producers have not been slow to attempt to capitalise on the new biology. The fermentation industry represents some 2-3\% of Japan's GNP.

Outside industry, government has also taken a strong interest, particularly through the Office for Life Science Promotion headed by Professor A Wada. This office has set up a systematic programme for the research and development of enzyme technology, and has made a detailed analysis of its possible impacts on industry and society. "The association between a well-defined plan and the Japanese potential is unique in the world" writes Thomas in his report.*

The recently published French report* suggests that Japan has chosen to make an all-out effort on biotechnology because of the potentially high added value the technology can give to imported raw materials. In a country as dependent on imports as Japan this is an important consideration.

Furthermore Japan already enjoys "a very high reputation as one of the principal world producers of antibiotics" through fermentation, and the country intends to maintain this position through its research. "It is clear that in Japan there is no official or conceptual division between basic and applied research; there is a continuous exchange of skills and services between universities and industry".

However there is a feeling that Japan is not as advanced as some other countries in fundamental biology, so international competition particularly through genetically engineered organisms is not closed.

\section{US catches up}

America is the second most advanced country in this field, judging by patents and production. "The patent list shows that industrial interest in enzyme technology is significant, but so far the only large scale application is the production of fructose syrups by several companies" writes Thomas.*

But he forecasts an "explosion" in applications which should flow from the Research Applied to National Needs programme of the National Science Foundation. A strong interdisciplinary team at the MIT has been focusing on the total enzyme synthesis of gramicidin, a cyclic decapeptide antibiotic. This problem tackles head on the major obstacle to application of synthetic as opposed to degradative pathways: the cost-effective provision and regeneration of small cofactor molecules such as ATP and NADH.

The country that finds a practical solution to this problem, and patents it, will find itself at a major advantage compared with others; but there is some scepticism about whether extra-cellular systems will ever be successful.

Some eight cell species have been successfully immobilised in the laboratory in the US: Streptomyces venezuelae and Bacillus sp (for producing fructose), Saccharomyces cerevisiae (invert sugar), $E$. coli (fumaric acid), Nocadia erythropolis ( $\Delta^{4}$-cholesterone), Corynebacterium simplex (prednisolone), Serratia marcescens (2-keto gluconic acid), and Corynebacterium lilium (glutamic acid).

Moreover the US is well-advanced in applied recombinant DNA techniques the production of somatostatin for research purposes being promised shortly, with insulin also on the way; and it has a very strong base in fundamental biology. Research and development organisations based on venture capital are very active (see Nature 278, 494; 1979), and at least one (Genentech) is active in recruiting scientists outside the US, particularly in Europe.

\section{Soviet secrecy}

Soviet commitment to biotechnology, indeed to all aspects of molecular biology, began officially with the decree of 21 May, 1974, which set Soviet science the task of "accelerating the development of molecular biology and molecular genetics" and the "wide use of their achievements in agriculture, medicine and industry". Considerable human and financial resources were committed to closing the 